<総 説 $>$

(受理 : 平成 20 年 9 月 1 日)

\title{
金属ナノ粒子ペーストの回路形成への応用 Metal Nanoparticle Paste and Its Application to Electronic Circuit and Packaging
}

\author{
松葉 頼 重* \\ Yorishige MATSUBA
}

\section{1.はじめに}

プリンタブルエレクトロニクスの基礎材料として, 金属 ナノ粒子を顔料とした導電性インク（ペースト）が幅広く 使われるようになってきた。いろいろな印刷機器と組み合 わせて, 回路配線, 電極形成, 有機トランジス夕, あるい はマイクロ接合への応用が進みつつある。従来のフォトリ ソプロセスに比べ工程を簡素化でき，工法によっては廃棄 物削減にも絶大な効果が期待されている。金属種としては 今のところ大気焼成が可能な銀が主流であるが，銅ナノ粒 子ペーストに関しても今後急ピッチに実用化が進むむのと 思われる。

一方，このような液体による配線技術（Liquid Wiring Technology）と親和性の高いデジタル印刷技術として, オンデマンド方式のインクジェット印刷が注目されている。 インクジェット印刷ではパターニングに必要な原版（マス ク）をパソコン内でバーチャルに管理・運用できるため, 最近市場二ーズの高い基板・素子のカスタム生産（多品種 少量生産）において大きな利便性が得られる。また, オフ コンタクト印刷の特徵を生かすことによって, 凹凸のある 基板上への配線形成も容易である。インクジェット工法の 実装分野への応用に関してはセミナー等も盛んに開催され ており, 解説書もいくつか発刊されている

本稿のテーマである回路形成の範疇には導電性材料以外, 抵抗体, コンデンサ, インダクタ等も当然含まれるが, こ こでは弊社で開発した金属ナノ粒子ペースト“ナノペース ト (NanoPaste)” のエレクトロニクス実装への応用にっ

\section{*ハリマ化成株式会社 筑波研究所}

茨城県つくば市東光台 5-9-3 テ 300-2635

Tsukuba Research Laboratory, Harima Chemicals, Inc.

5-9-3, Tokodai, Tsukuba, Ibaraki 300-2635, Japan
いて紹介したい。また印刷工法としては，ここ数年で大き な発展を見せているインクジェット技術を中心に解説する。

\section{2. 金属ナノ粒子ペースト}

\section{1 ナノペーストの基本構成}

金属ナノ粒子の製造法は物理的方法と化学的方法とに大 別される。物理的方法の中で, ガス中蒸発法は量産規模へ の見通しが得られている技術であり，コンタミのない数 $\mathrm{nm}$ サイズの金属ナノ粒子が得られる ${ }^{3)}$ 。一方, 化学的方 法には数多くのプロセスがあり, 月産トンレベルの生産に 適用できるものも含まれる。いずれも生成した金属ナノ粒 子を粗大化させずに安定なコロイド状態に転換する技術が 重要である。この点, 金属錯体を前駆体とした熱分解ある いは還元による方法は, 分散系の安定化と高濃度化の両面 で有利であり, 合金ナノ粒子への発展性む含めインク化の 実用的なアプローチとして注目される4)。

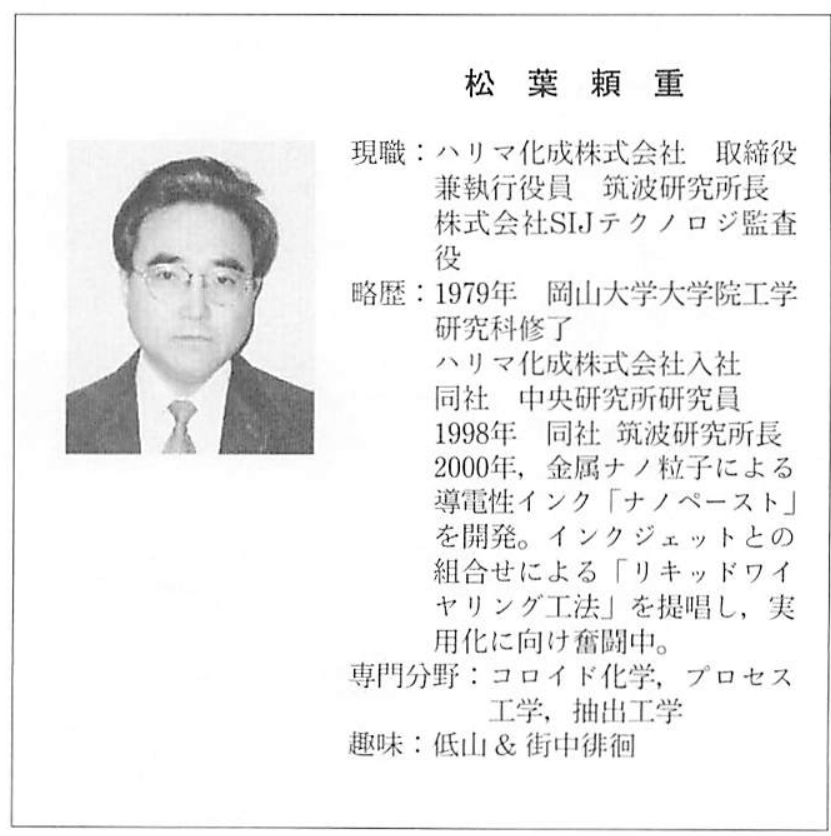


ナノペーストは粒子サイズが $10 \mathrm{~nm}$ 以下の金属ナノ粒子 を有機溶媒中に単分散したもので, 高濃度であ分散安定性 を損なわないよう，ナノ粒子表面は有機物で被覆されてい る5)。金属ナノ粒子は, いわゆる量子サイズ効果によって 融点がバルク金属よりも低下することが知られている ${ }^{6)}$ 。 ナノペーストの設計コンセプトにむこの考えが取り入れら れており, 金属種に関わらず $200^{\circ} \mathrm{C}$ 前後での焼成が可能で ある。しかし，金属ナノ粒子の示すこのような融点降下現 象は, 金属ナノ粒子の集合体からバルク構造の金属がダイ レクトに生じることを保証するものではない7)。文献等で “加熱によって不安定化した分散剤が金属ナノ粒子表面か ら脱離し，その後は活性表面の露出した隣接するナノ粒子 間で自発的に融合が進む”といった解説が散見されるが, 実際の焼結プロセスはこのような単純なものではなく，有 機物および金属原子の同時拡散を伴う複雑なプロセスで進 行するあのと考えられる。

\section{2 金属ナノ粒子からのバルク構造形成}

金属ナノ粒子を焼結させる最も簡便で実用的な方法は, 焼成炉（オーブン）による加熱である。図 1 に熱風循環式 オーブン中で加熱した場合の銀ナノペーストの比抵抗と温 度との関係，並びに温度による燒結構造の違いを示す。焼 成温度が高いほど比抵抗は低くなり， $200^{\circ} \mathrm{C}$ 以上では銀の
比抵抗である $1.6 \mu \Omega \cdot \mathrm{cm}$ に近い值となる。一方, 燒結 体の内部構造は $220^{\circ} \mathrm{C}$ (d) では銀めっき（a）に匹敵するほ ど緻密であるが， $200^{\circ} \mathrm{C}$ (c) では比抵抗は同等であるにあ 関わらず結晶成長がかなり抑制され， $180^{\circ} \mathrm{C}$ (b)ではもは や砂粒を集めたような粗い構造しか得られない。このこと は, ナノ粒子のバルク金属化のレベルを推し量るのに抵抗 測定だけでは不十分であることを意味しており，金属ナ， 粒子ペーストを配線材等に使って信頼性不足に陥る最大の 要因がここにあることを忘れてはならない。

金属ナノ粒子ペーストの焼成には, 装置コストおよび操 作の簡便さから一般に上述のような焼成炉による加熱が用 いられる。しかし，回路基板上の限られた部分に配線形成 したい場合，あるいは部品実装したあとで追加的に金属ナ ノ粒子インクによる加工を施したい場合には，基板全体に 熱負荷のかかるこの方法は合理的とはいえない。このよう なことから、レーザーによる短時間焼成技術が検討されて いる。レーザーには低温焼成だけでなく，スポット径を絞 ることで焼結ラインを高解像度化できるメリットあある ${ }^{8)}$ 。

図 2 は銀ナノペーストの焼成をオーブン加熱とレーザー 照射とで比較した外観写真である ${ }^{9)}$ 。表面の凹凸はインク ジェットによる着弾痕であるが, レーザー焼成の方が滑ら かな表面が得られている。また，焼成時間もオーブンでは 1 時間程度を要するのに対して, レーザーの場合わずか数

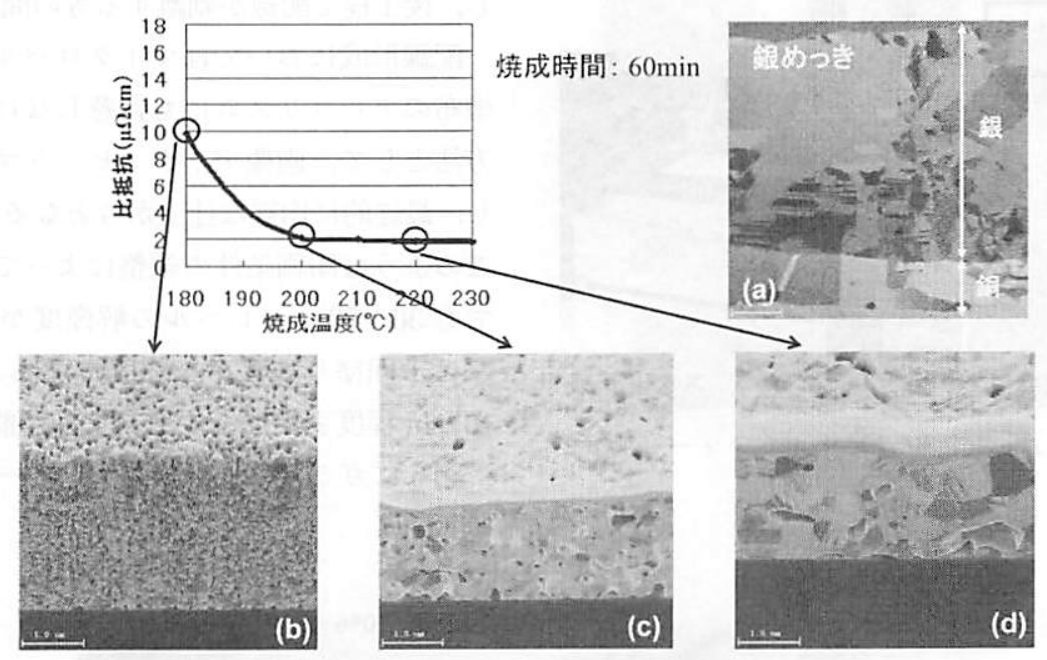

図 1 焼成温度の比抵抗・内部構造への影響

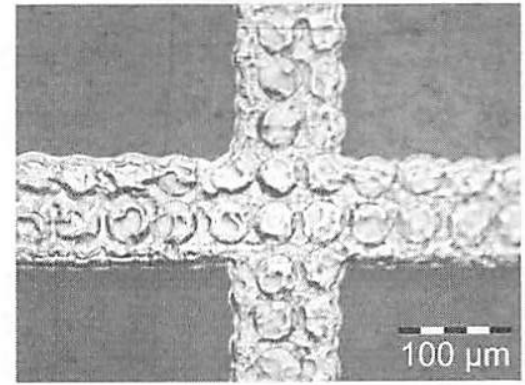

(a) オーブン加熱 : $220^{\circ} \mathrm{C} \times 1 \mathrm{hr}$

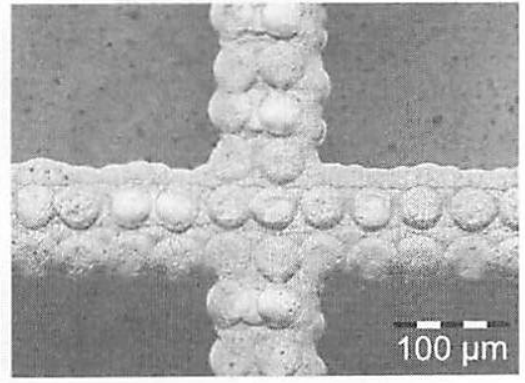

(b) レーザー照射 : 20sec

図 2 オーブン加熱とレーザー照射との比較 
十秒で完結している。焼成時間がここまで短いと，レーザー 機構が組み込まれた産業用インクジェット装置の開発が待 たれるが，すでにYAGレーザーによる技術開発が進めら れている ${ }^{10)}$ 。また実用上の成果として，銀ナノペーストの レーザー焼成膜がめっき代替被膜として機能することが確 梕されている11)

レーザーも基本的には加熱方式による焼成であるが，金 属ナノ粒子の分散剂をアルコールで脱着させることで，常 温焼成する“化学焼結 (Chemical Sintering)” と屯呼ぶ

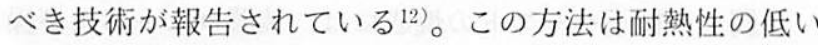
$\mathrm{PET}, \mathrm{PEN}$ 等の基材への配線形成に有効之考えられ, 今 後実用化が期待される。

\section{3. 印刷工法}

\section{1 インクジェット印刷}

産業用インクジェットプリンタは，待機時間を最小にし て長時間にわたる印刷作業に耐えなければならない。その ため,インクジェット印刷用の顔料インクの設計において は室温での長時間にわたる安定性が要求される。プリント

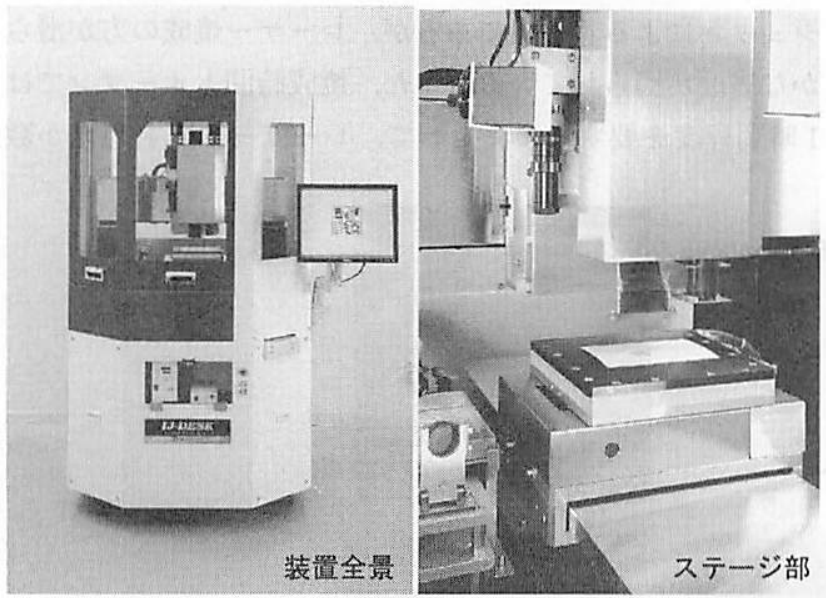

図 3 配線用インクジェット装置（ピーエムティー社製）

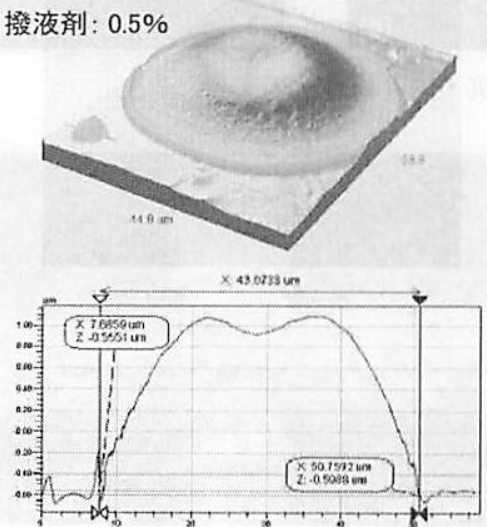

(a)
ヘッドは通常マルチノズルなので, 詰まったノズルのソフ トウエアによるバックアップ処理も可能ではあるが，印刷 速度はかなり低下することになる。ノズル閉塞は主にイン ク中に含まれる顔料の凝集が原因であり,ヘッド材質とイ ンクとのマッチングが非常に重要である。

図 3 に配線形成用に開発されたインクジェット試験装置 の外観と印刷ステージ部の写真を示す。この装置にはノズ ル数 128 のステンレス製プリントヘッドが搭載されており, 100 150mm/s の非常に速い塗布速度を特徴としている。 ナノペーストによる長時間塗布が可能で, 本稿で示すイン クジェットの印刷事例は，この装置と同じ基本構造を持つ プロトタイプ機で描画されたものである。

インクジェット印刷では基材の撥液処理とステージ加熱 とのバランスが重要である。図 4 に銀ナノペーストをポリ イミドフィルム上にインクジェット塗布した際の着弾イン クのドット形状を示す ${ }^{13)}$ 。

(a) はフッ素系の撥液剤であるノベック EGC-1720（住 友スリーエム社製）が $0.5 \%$ （b）は $10 \%$ で表面処理した 場合の結果である。ドット径书よび高さは撥液㓮濃度によっ て大きく変わり,（a）で $43.7 \times 1.6 \mu \mathrm{m}$, (b) が $36.2 \times 2.9 \mu \mathrm{m}$ となっている。（b）の方が好ましい状態であることは言う までむないが, あまり強めに撥液処理を施すと, 焼成過程 で撥液剤が完全に熱分解せずに燒成膜と基材との間に残留 し, 後工程で配線が剥離する等の問題を生じることがある。 配線形成においてはマイクロバルジの発生を防ぐため, 塗布のアルゴリズムにあ留意しなければならない。具体的 方法として, 画像データ（ビットマップ）を分割して塗布 し, 最終的に均質な仕上がりとなるような工夫がとられる。 このような印刷条件の調整によって, 一般の産業用へッド でも 30 50 $\mu \mathrm{m}$ レベルの解像度が得られる。燒成後の膜 厚は 1 回塗りで $3 \mu \mathrm{m}$ 程度であるが, 重㛊叙りによって $10 \mu \mathrm{m}$ 程度まで厚くすることも可能である。

図 5 にガラス基板上に銀ナノペーストをインクジェット

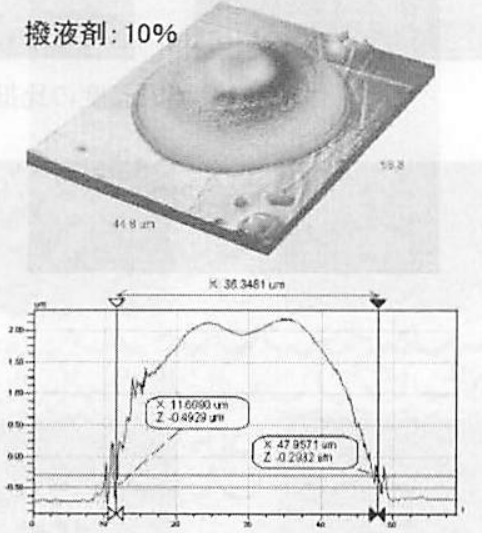

(b)

図 4 インクジェット着弾径への撥液剤の効果 


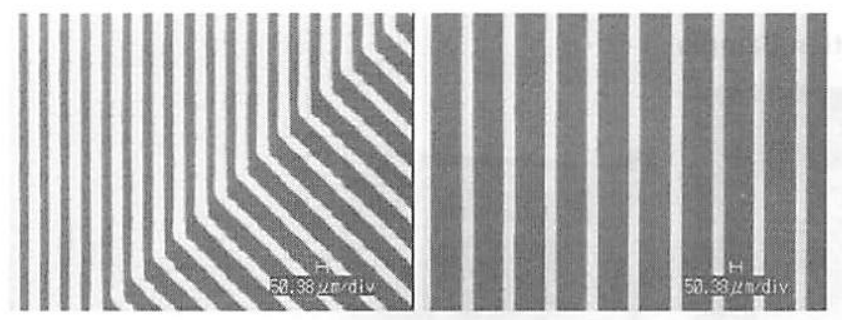

インク:銀ナノペースト 基材:ガラス

焼成: $200^{\circ} \mathrm{C}, 1 \mathrm{hr}$

図 5 撥液処理と基板加熱を併用した高精細印刷

塗布して形成した配線パターンを示す。着弹痕は上述の撥 液処理と塗布アルゴリズムの最適化によって, まったく目 立たないレベルまで抑制されている。また，サテライト滴 の発生による配線間の污染もなく, 約 $50 \mu \mathrm{m}$ 幅の均質な 配線が得られている。

インクジェットを実装用途で使う場合，相手となる基材 は平滑な表面を持つ紙やフィルムとは限らず，極端なケー スでは事前に部品が搭載された基板であることも想定しな ければならない。すなわち，プリントヘッドを基板から上 方にかなり離した状態でも正確な印刷ができる必要がある。

図 6 にノズル先端と基板とのギャップによる影響を示す。 通常インクジェット印刷では $1 \mathrm{~mm}$ 以下のギャップがとら れるが，銀ナノペーストを用いたこの赛験では $4 \mathrm{~mm}$ 程度 まで開いても印刷パターンの乱机はほとんど観測されなかっ た。こ机は，銀ナノペーストの密度が高く飛翔の直進性が よいこと，ノズル開口部とインクとの濡れ性が一定に保た れていること，およびへッドの駆動条件（波形等）が適正 であることが寄与している。凹凸のある基板表面への自由 な描画を可能にするこの結果は, インクジェット工法の適 用領域を拡げるものである。

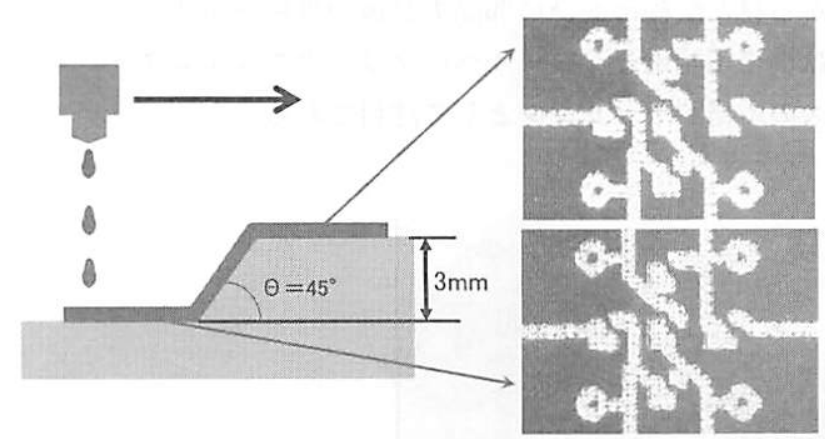

図 6 インクジェット印刷時のギャップの影響

\section{2 スクリーン印刷およびフレキソ印刷}

スクリーン印刷はンルダペースト, レジストインク, 導 電性ペーストなどの塗布工程で寒績のある汎用性の高い印 刷工法である ${ }^{14}$ 。ナノペーストの印刷にあ同様に利用でき, 特にフレキシブル基板に対してはロールッーロール方式に よる大量処理にむ対応可能である。通常の導電性ペース卜

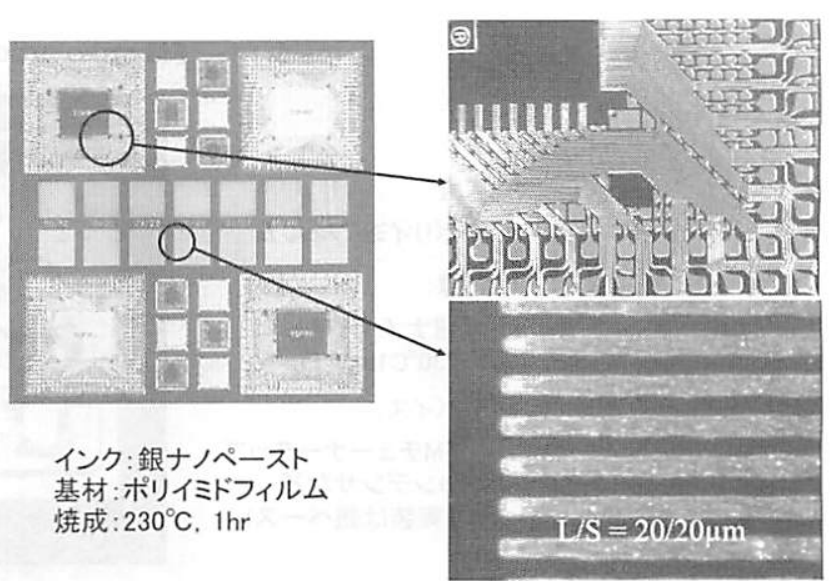

図 7 スクリーン印刷の描画品質

ではフィラーである金属粒子の粒径による制限から解像度 に限界があるが，ナノペーストでは染料インクと同じ扱い が可能であり，より高精細な印刷に用いることができる。

図 7 に銀ナノペーストのポリイミドフィルム上へのスク リーン印刷結果を示す (焼成温度 $230^{\circ} \mathrm{C}$ )。印刷版をうま く管理することによって，ここに示すように $20 / 20 \mu \mathrm{m}$ の ライン/スペースにまで対応可能である。ただし写真から は判別し難いが, 印刷版の紗の影響が多少なりとむ出てく る問題は避け難い。ナノペーストを用いたスクリーン印刷 の事例としては, ウエハレベルパッケージ（WLP）の再 配線，タッチパネルの電極形成等一の適用実績がある。

図 8 にフレキッ印刷の結果を示す。解像度としてはスク リーン印刷を上回るむのがあるが，塗布厚を稼ぐことがで きず，しかむ表面はレベリングせずに荒れた状態となって いる。金属ナ/粒子の分散インクはレオロジーコントロー ルの調整幅が狭いため, 転写性に優れたペーストの設計に はかなりの工夫が必要である。

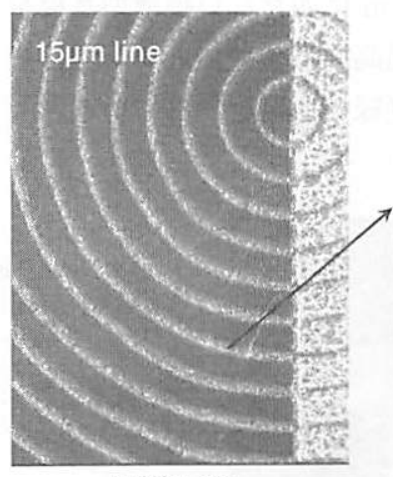

印刷ライン

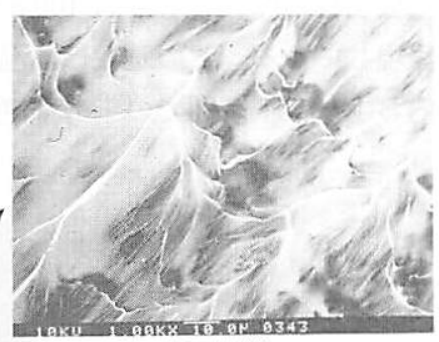

表面状態

インク:銀ナノペースト 基材:ポリイミドフィルム 焼成: $230^{\circ} \mathrm{C}, 1 \mathrm{hr}$

図 8 フレキソ印刷の描画品質

\section{4. 応用事例}

\section{1 回路基板およびシステム・イン・パッケージ $(\mathrm{SiP})$ への応用}

産業用のインクジェット装置とナノペーストによる応用 


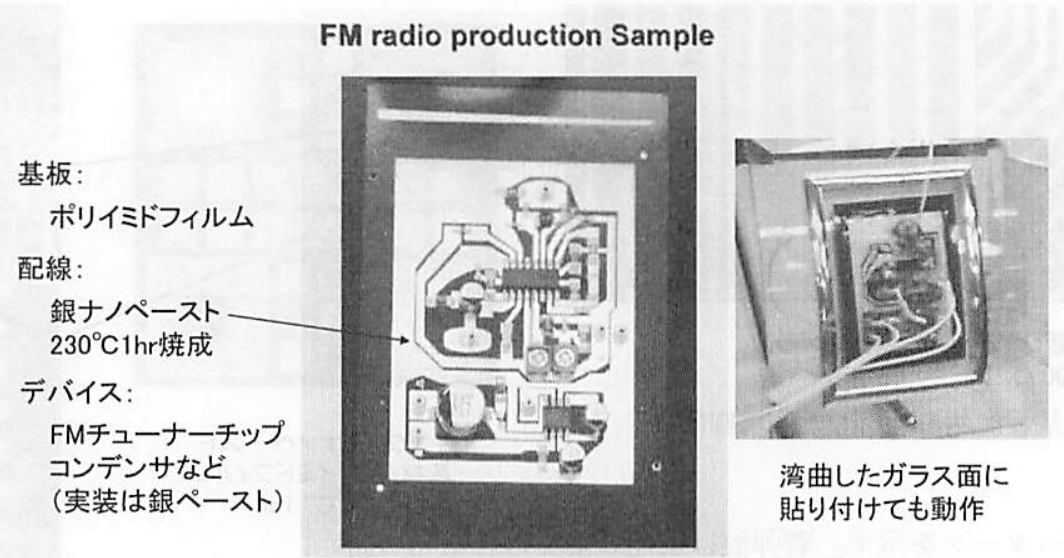

図 9 FM ラジオの試作

事例を紹介したい。図 9 に示したのはポリイミドフィルム 上に銀ナノペーストを用いて配線形成し, IC チップと周 辺部品を搭載してフレキシブルな FM ラジオを試作した 例である。湾曲したガラス面に貼り付けてもこのラジオは 正常に動作し, 各種モバイル機器においてデッドスペース となっているケース内面（曲面である場合が多い）の機能 化に利用できそうである。あちろん，凹凸の少ない面であ れば, 基板の貼り付けなしに直接ヶース内に配線形成する ことも可能と思われる。

単層から多層化への試みとしては, 銀ナノペーストを用 いてフレキシブルな 5 層ビルドアップ基板の試作に成功し ている ${ }^{15}$ 。図 10 にこの基板の外観と配線部の写真を示す。

絶縁層は液状のポリイミド樹脂をべ夕印刷後に加熱硬化 させて形成しており, 第 1 層は剥離剤で前処理したガラス 基板上に作製した。層間導通のためにレーザービア加工を 施し、このビア部にも銀ナノペーストをインクジェットで 埋め込んでいる。その結果, 配線部 $5 \mu \mathrm{m}$, 絶縁層 $15 \mu \mathrm{m}$, 基板全体の厚みとしては $100 \mu \mathrm{m}$ に満たない超薄型基板を 実現している。この基板は高温高湿試験において, 配線層 内捄よび上下層間での十分な絶縁性が確認されている。
次に, プログラム実装コンソーシアムの成果として, 部 品内蔵型 $\mathrm{SiP}$ を試作し, LED ドライバーとして動作させ ることができた ${ }^{16) 。}$

図 11 に示すように, LED 駆動制御用の IC3 個, チップ コンデンサ 10 個，チップ抵抗 3 個が樹脂モールドにより 電極部を同一平面上に露出させる形で一体化され，電極 間を銀ナノペーストによって配線する工法が用いられてい る。図の右下部に示すように LED の点灯か確認されてお り,このときの動作電流は $0.49 \mathrm{~mA}$, 電圧は $2.5 \mathrm{~V}$ であっ た。なお，この $\mathrm{SiP}$ 試作では上述の 5 層基板の場合と異 なり，絶縁層むインクジェットで形成しているのが特徵で ある。

同様の方法で，さらに高密度の $\operatorname{SiP}(R F$ モジュール) を試作した事例を紹介したい13)。工法としては配線形成 の全工程にインクジェットが使われたわけではないが，埋 め込み型のコア IC に加えて 21 個もの受動部品が実装さ れており，パッド数は実に 102 に及ぶ。図 12 に基板裏面 から見た配線部並びに部品実装後の外観を示す。この研究 は携帯電話用モジュールへのプリンタブルエレクトロニク スの本格的チャレンジとして注目される。

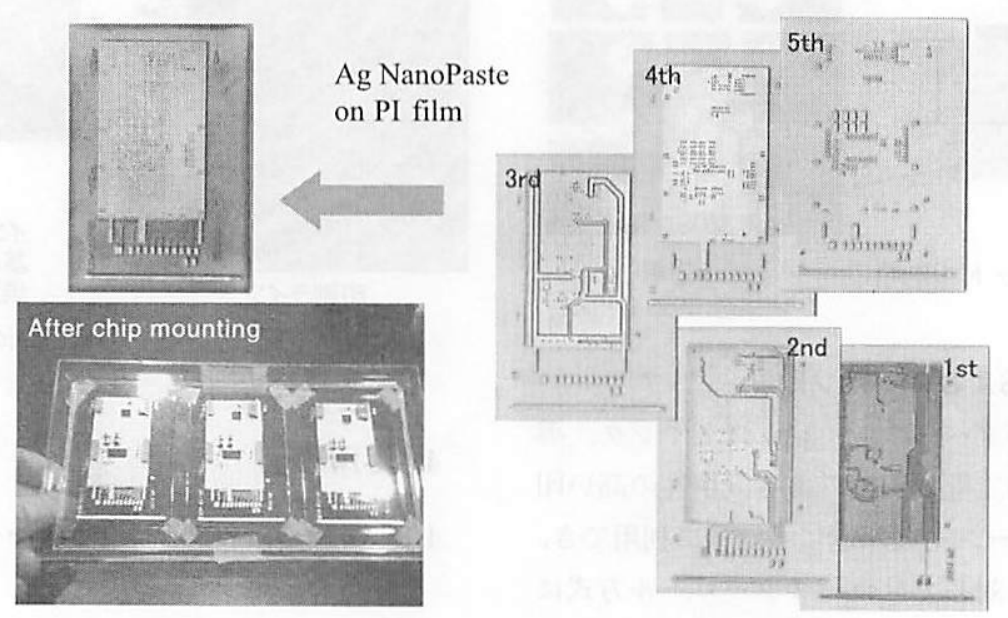

図 10 インクジェット工法で試作した 5 層配線基板 


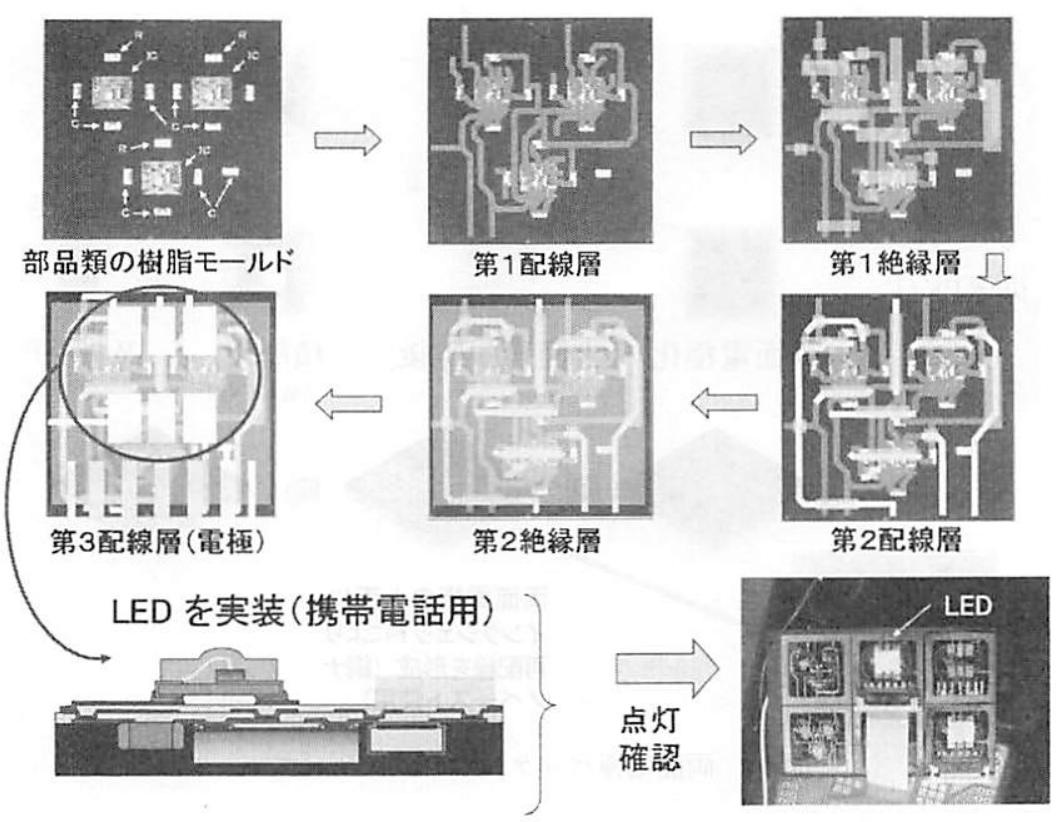

図 11 LED モジュールの試作

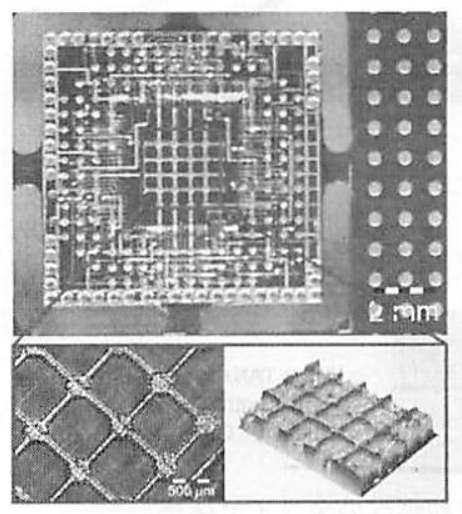

背面から見た配線層
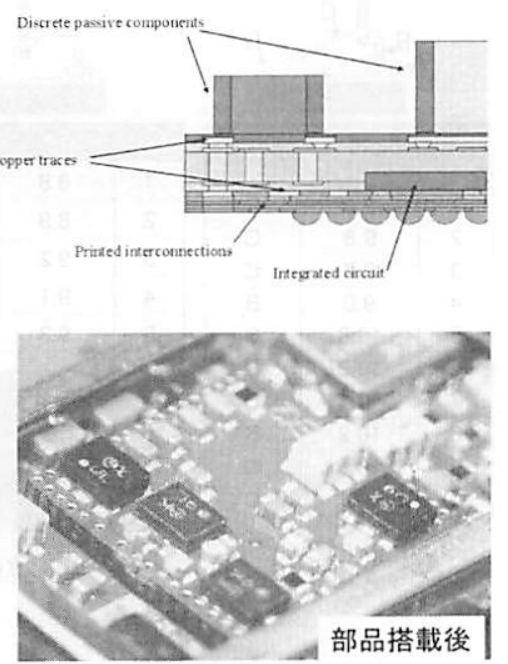

図12 インクジェットで作製された携帯電話モジュール

現在普及している MCP (マルチ・チップ・パッケージ) では, ベアチップの良品判定および組合せの自由度の問題 が潜在的課題としてあり，これに替わる手段としてパッケー ジそのあのを積層する PoP (パッケージ・オン・パッケー ジ）が注目されるようになってきた。PoP 構造をつくる ユニークな試みとして, 従来利用されていないパッケージ 上面にも電極を形成し，再配線することで自由な組合せの パッケージをつくる手法が提案されている ${ }^{17) 。 ~}$

図 13 に試作サンプルを示す。ベースパッケージは $13 \mathrm{~mm}$ 角で厚み $0.4 \mathrm{~mm}$, 電極数は上面 106 , 下面 220 である。上 面のインクジェットによる再配線には耐マイグレーション 性を考慮して銅ナノペーストが用いられている。銅ナノペー ストの場合, 何らかの還元燒成プロセスが必要であるが, この研究では原子状水素を用いた還元炉の適用が検討され ている。

\section{2 接合材としての利用}

接合用途では，金ナノペーストを従来の金めっき代替と して用いて, ワイヤボンドが可能であることが確認されて いる ${ }^{15)}$ 。現在, 半導体接合においては金ワイヤボンディン グ接合が主流であり, 半導体を接続する相手側のインター ポーザには主に金めっきが施されている。この金めっきの 代替として, インクジェット装置を用いて金属表面の必要 箇所にのみ金ナノペーストを塗布・焼成することで, 工程 を大幅に簡略化でき, 従来のウエットめっき工程に付随し た廃液処理を不要にするなど大きなメリットが得られる。

図 14 に銅基板上に形成した金ナノペーストの焼成被膜 上に金ワイヤボンディングをした場合の強度評価結果を示 す。プル強度, シェア強度の測定結果から, 従来の電解めっ きによる金被膜への接合強度と同等であることが確認され た。 


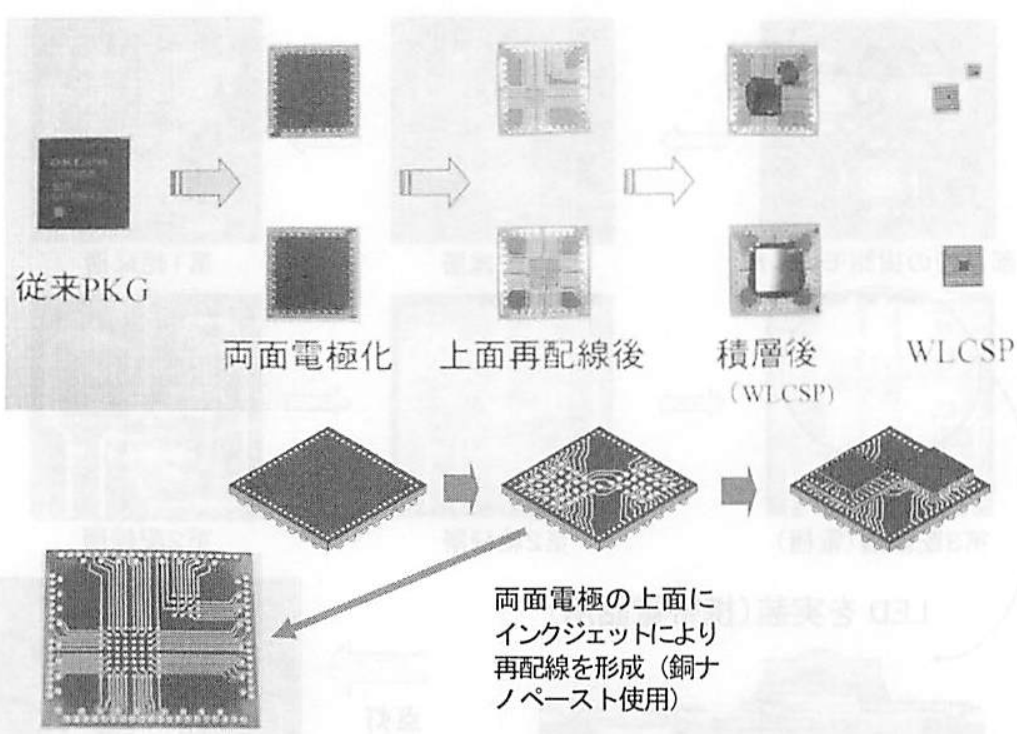

図 13 両面電極パッケージの試作サンプル

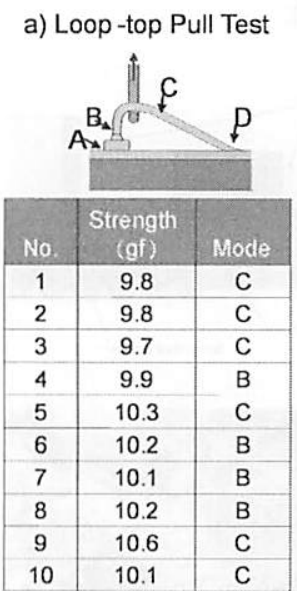

b) Loop -center Pull Test

C) Shear Test

図 14 金ナノペースト焼成被膜への金ワイヤ接合
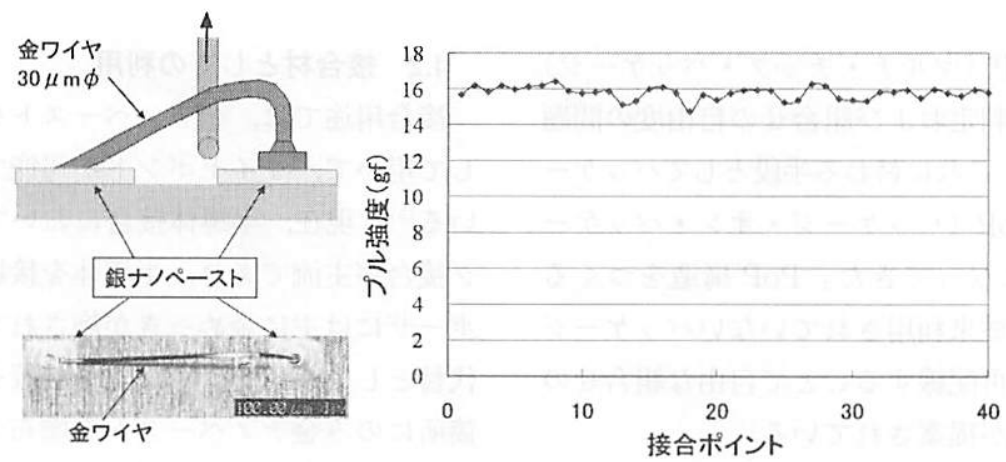

図 15 銀ナノペースト焼成被膜への金ワイヤ接合

同様に，銀ナノペーストを銀めっきの代替として使える ことも確認されている。図 15 に示すように，銅板上に銀 ナノペーストをインクジェットで塗布し， $270^{\circ} \mathrm{C}$ で 15 分間 焼成して接合パッドを形成した。そこに直径 $30 \mu \mathrm{m}$ の金
ワイヤを超音波接合し，ループセンターでのプル強度を測 定したよころばらつきの少ない高強度の接合が得られた。 分析したところ燒成膜の内部構造はほぼ完全なバルク構造 となっており，これが銀めっきと同等の性能を与えている 


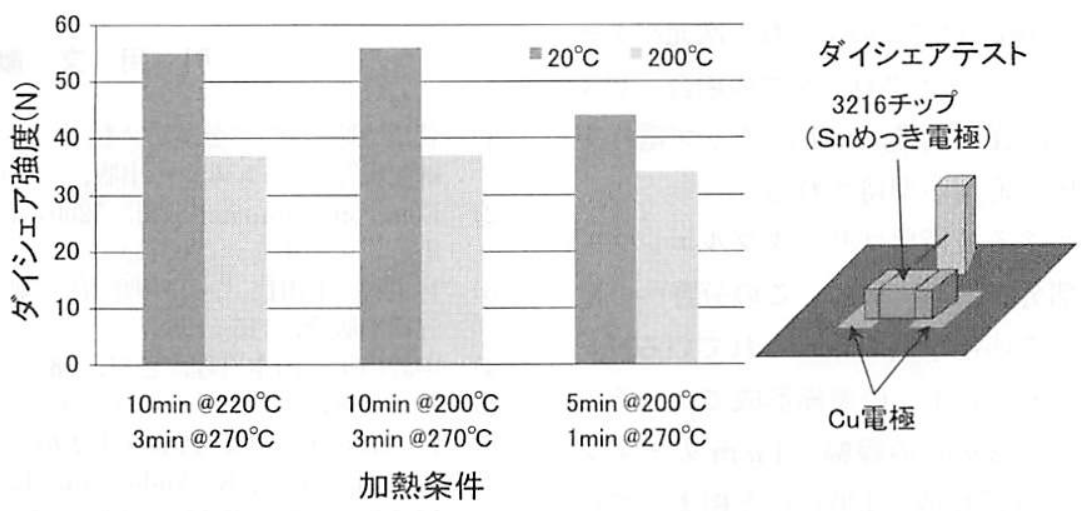

図 16 銀ナノペーストによるチップ接合

あのと考えられる。

金属ナノ粒子を導電性接着剤として利用する試みもみら れるようになってきた ${ }^{18,19)}$ 。量子サイズ効果で融点降下し た金属ナノ粒子を, 一種の糊として接合に使おうとする考 えである。実際には，ナノ粒子を覆っている有機成分の蒸 散が関与するため課題点むあるが，今後はんだ接合に替わ る新しい接合技術として実用化される可能性が高い。

図 16 に簡単な接合実験の事例を示す。手順としては, フラックスを塗布した銅電極上に銀ナノペーストをディス ペンサで一定量供給し，その上にチップ両端面に錫めっき 処理された銅電極を有する 3216 チップを搭載して, 各種 リフロー条件で焼成した。ダイシェアテスターでシェア強 度を测定したところ，室温 $\left(20^{\circ} \mathrm{C}\right)$ ではんだ接合と同等の 強度が得られ, 高温 $\left(200^{\circ} \mathrm{C}\right)$ で屯強度劣化が少ないこと が確認された。加熱条件はほぼ鉛フリーソルダのリフロー 条件に類しており，金属ナノ粒子の有する高熱伝導性およ び高耐熱性を生かした高温はんだ代替の接合材として活用 が期待される。

\section{3 スーパーインクジェットによる特殊印刷}

現在家庭用として広く普及しているピエゾ方式のインク ジェットプリン夕は, 高精細のものであ最小滴径は $1 \mathrm{pl}$ （ピコリットル）が限界である。しかし，これは球換算で は約 $12 \mu \mathrm{m}$ に相当し, “ピコ”という語感から連想するよ りはかなり大きい。産総研で開発されたスーパーインクジェッ ト（SIJ）技術はfl（フェムトリットル）の昍出技術を実 現し, 超高精細・直接描画に向けたインクジェットのフロ ンティア領域を切り開きつつある20)。

SIJ では, 吐出するインク滴径が $1 \mu \mathrm{m}$ 以下と微小であ るため, インク吐出後に急速な溶剤の蒸発が起こり, 着弾 点では金属ナノ粒子が濃縮された高粘度液体に変化する。 これによって, インクジェットの宿命であるマイクロバル ジの発生は抑制され, 図 17 に示すような特殊なマイクロ ファプリケーションが可能となる。

（a）は線幅 $3 \mu \mathrm{m}$ の微細な平面パターン，（b)〜（d）は マイクロスケールの立体形成の事例である。一般のインク ジェットによる立体造形では，レーザーやUVによる有 機モノマーの硬化システムが利用されるが, SIJでは何ら
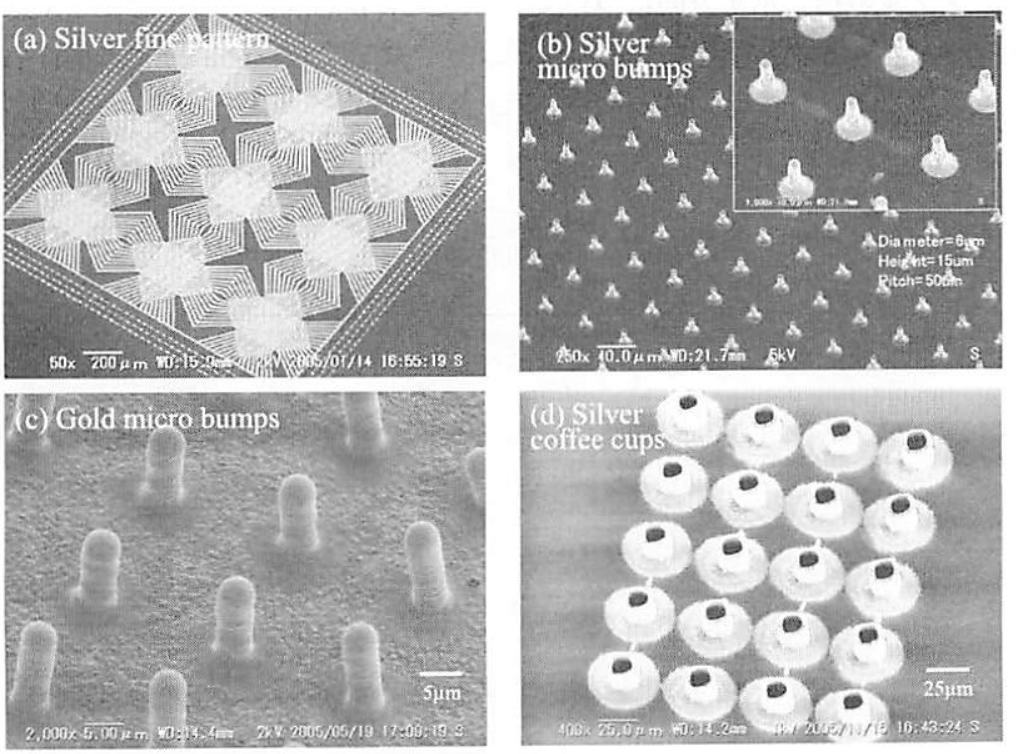

図17 スーパーインクジェットによる試作サンプル 
の支援システムなしに，印刷だけでこのような三次元パター ンの形成が可能である。(b) のマイクロバンプの場合, ピッ チ $50 \mu \mathrm{m}$, 高さ約 $15 \mu \mathrm{m}$, 径は約 $6 \mu \mathrm{m}$ で, チップ電極を はじめ実装分野での幅広い応用が期待される。

有機トランジスタをめぐる技術はプリンタブルエレクト ロニクスのハイライト部分を占めている。この分野への電 界吐出型インクジェットの応用事例が報告されている ${ }^{21}$ 。 また, SIJによるソース・ドレインの電極形成では, その 超微細印刷性を生かして, $2 \mu \mathrm{m}$ の線幅, $1 \mu \mathrm{m}$ のチャン ネル長を実現しており，低温焼成 $\left(130^{\circ} \mathrm{C}\right)$ と相まってぺ ンタセン層へのダメージを極小化し, 高性能有機 TFT の 構造形成に大きく寄与している222。スーパーインクジェッ トは現状では大面積のパターン形成には向かないが，微小 部分への機能形成には実用性の高い技術といえる。

\section{5.おわりに}

金属ナノ粒子については特性面もブラッシュアップされ, 実用材料の域に達しつつある。この流れが引き継がれれば, エレクトロニクス実装に必要なあらゆる材料がプリンタブ ルなインクの対象となる。形態も液体だけでなく, トナー のような粉体, 転写テープのような固体, あるいはェアロ ゾルのような気体状のものも予想される。インクの多様化 とそれに伴う印刷技術の革新が今後どのように進むのか注 目していきたい。

プリンタブルエレクトロニクスは新しいモノづくり技術 への萌芽を含むあのである。しかし，この概念を拡大解釈 して, 本来既存技術で満足すべき領域にまで立ち入ってし まわないよう注意しなければならない。そこに印刷でしか 実現できない何かがなければ，単に“印刷でもここまでや れた”という自己満足的な世界に終始することとなる。こ の分野がひとつのテクノロジー分野として確固たる地位を 獲得するためには, プリンタブルの指し示す方向について 深い議論を重权, 装置・材料・プロセス技術が一体となっ て進化していく必要がある。

\section{引用 文 献}

1）菅沼克昭監修，“金属ナノ粒子ペーストのインクジェット微 細配線”，シーエムシー出版，（2006）.

2）Electronic Journal 別冊,“2007 インクジェット技術大全”, 電子ジャーナル, (2007).

3）林主税, 上田良二, 田崎明 編, “超微粒子一创造科学技術”, 三田出版会, 115 (1988).

4) 中許昌美, 山本真理, 色材, 78, 221 (2005).

5）松葉頼重, エレクトロニクス実装学会誌，6，130 (2003).

6) Ph. Buffat and J-P. Borel, Phys. Rev. A, 13, 2287 (1976).

7) Z. Radivojevic, K. Andersson, K. Hashizume, M. Heino, M. Mäntysalo, P. Mansikkamäki, Y. Matsuba, N. Terada, Proc. THERMINIC 2006 (Nice), 163 (2006).

8) S. H. Ko, H. Pan, C. P. Grigoropoulos, C. K. Luscombe, J. M J Frechet and D. Poulikakos, Nanotechnology, 18, 1 (2007).

9) J. Pekkanen, M. Heino, P. Mansikkamäki, M. Mäntysalo and R. Rönkkä, Abstracts of Nanotechnology in Northern Europe Congress 2007 (Helsinki), 78 (2005).

10) K.Maekawa, M.Mita, K.Yamasaki, T.Niizeki, Y.Matsuba, N. Terada and H. Saito, Proc. ECTC 2008, 950 (2008).

11) T.Niizeki, K. Maekawa, M.Mita, K.Yamasaki, Y.Matsuba, N. Terada and H. Saito, Proc. ECTC 2008, 1745 (2008).

12) D. Wakuda, M. Hatamura and K.Suganuma, Chem.Phys. Lett., 441, 305 (2007).

13) M. Mäntysalo, P. Mansikkamäki, J. Miettine, K. Kaija, S. Pienimaa, R. Rönkkä, K. Hashizume, A. Kamigori, Y. Matsuba, K. Oyama, N. Terada, H. Saito, M. Kuchiki and M. Tsubouchi, Proc. ECTC 2007, 89 (2007).

14）佐野康，“高品質スクリーン印刷ガイド”，エスピーソリュー ション, (2007).

15）小山㹂秀, 松葉頼重, エレクトロニクス実装学会誌， 9, 538 (2006).

16）小田正明，電子材料， 44, 55 (2005).

17）石原政道，和泉亮，エレクトロニクス実装学会誌，10，403 (2007).

18）廣瀬明夫, 溶接学会誌, 76, 162 (2007).

19) H. Jiang, K-S Moon, F. Hua and C. P. Wong, Chem. Mater., 19, 4482 (2007).

20）村田和広，エレクトロニクス実装学会誌，7，487 (2004).

21) J-U. Park, M. Hardy, S. J. Kang, K. Barton, K. Adair, D.K.Mukhopadhyay, C.Y.Lee, M.S.Strano, A.G.Alleyne, J. G. Georgiadis, P. M. Ferreira and J. A. Rogers, Nature Mater., 6, 782 (2007).

22) T. Sekitani, Y. Noguchi, U. Zschieschang, H. Klauk and T. Someya, PANS, 105, 4976 (2008). 